The Eclipse of August 19, 1887.

THrs eclipse will be seen over such an extent of territory that it is desirable to make the best use of the opportunity offered. The astronomical observations I do not mention, but besides them the following would be very important, and could be made by travellers alone, and those who do not take with them heavy and troublesome instruments :-

Observations every ten minutes on the pressure and temperature of the air from the beginning of the eclipse to about half an hour after its end; and, some days before and later, every hour, at the hours of the eclipse.

The barometer might as well be an aneroid, but with large divisions; a pocket instrument would be too small. Relative and not absolute measures are intended, and it is especially necessary that the instrument be not sluggish.

The thermometer preferable for the observations should be a sling-thermometer (Frowde), as one in a thermometer-stand and not swung could not follow rapidly enough the changes of temperature. It would be best to swing it at the height of the shoulder.

Observations on cloud, direction and force of wind, every half hour the day of the eclipse and every hour before and later.

Some observations on the colour of the sky, \&c., and on the influence of the eclipse on animals, domestic and wild, would be useful.

The eclipse will be visible in Eastern Germany, but at so early an hour in the morning that there will be comparatively little interest in meteorological observations. Russia (especially Eastern) and Western and Central Siberia give much better opportunities of observation. I give below some notices on the amount of cloud ; the stations are disposed from west to east, the mean is that of three observations, 7 a.m., I p.m., and 9 p.m. The conditions as to cloudiness will be better than those indicated here, in Eastern Russia and Siberia to nearly Lake Baikal, as the eclipse will be seen in the later morning hours, which have a smaller amount of cloud than 7 a.m. and I p.m.

\section{Amount of Cloud.}

\begin{tabular}{|c|c|c|c|c|c|c|c|}
\hline & & & & & & & \\
\hline Rjev, Govern & & Tve & $\cdots$ & & 57 & $\ldots$ & \\
\hline Moscow ... & $\ldots$ & $\ldots$ & & $\ldots$ & 57 & ... & 5 \\
\hline $\begin{array}{l}\text { Academy of } \\
\text { Rojdestwensk }\end{array}$ & $\begin{array}{l}\text { etro } \\
\text { ye, }\end{array}$ & $\begin{array}{l}y, n \\
\text { yern }\end{array}$ & & & 5 & & \\
\hline troma $\ldots$ & $\ldots$ & $\ldots$ & $\ldots$ & $\ldots$ & $6 c$ & $\ldots$ & \\
\hline Kasan $\ldots$ & $\ldots$ & $\ldots$ & $\cdots$ & $\ldots$ & 58 & $\cdots$ & \\
\hline Viatka ... & $\ldots$ & $\ldots$ & $\ldots$ & $\ldots$ & & $\ldots$ & \\
\hline Ekaterinburg & $\ldots$ & $\ldots$ & $\ldots$ & $\ldots$ & 68 & $\ldots$ & \\
\hline guilsk & $\ldots$ & $\ldots$ & $\cdots$ & $\cdots$ & 64 & & \\
\hline Bogoslovsk & $\ldots$ & $\ldots$ & $\cdots$ & $\ldots$ & 57 & & \\
\hline Irbit $\quad \ldots$ & $\cdots$ & $\cdots$ & $\cdots$ & $\cdots$ & 53 & & \\
\hline 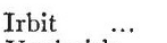 & $\cdots$ & $\cdots$ & & $\cdots$ & & & \\
\hline Yeni & $\cdots$ & $\cdots$ & $\ldots$ & $\cdots$ & 53 & & \\
\hline Irkuts & $\cdots$ & $\cdots$ & $\cdots$ & .. & 49 & $\cdots$ & \\
\hline lry of 1 & & & $\ldots$ & .. & 53 & $\cdots$ & \\
\hline fiigata, west & coast & $\mathrm{Ni}$ & & $\ldots$ & 55 & & \\
\hline
\end{tabular}

I give a list of some places where tolerably good accommodation is to be found, with the time of travel from the nearest railway-station :-

Tver, Torjok, Moscow, ${ }^{1}$ Yaroslav, ${ }^{2}$ Kostroma (three hours' steamer from latter point), Schuja, Ivanovo-Wosnessensk, Kineschma, Vladimir, Viatka (stéamer on Volga, Kama, and Viatka, from Nijni-Novgorod, in three days), Perm (steamer from Nijni-Novgorod in eighty-five hours.

Nijnetaguilsk, with important foundries, malachite mines, \&c., reached by railroad from Perm in fifteen hours.

Tobolsk, by rail from Perm to Tjumen in about thirty hours, thence by steamer in two days, twice a week. It is well to telegraph beforehand to retain a cabin.

Tomsk by steamer from Tjumen in about eight days, by the Tura, Tobol, Irtysch, and $\mathrm{Ob}$.

The places eastward, the most favourable for observation, can be reached by road only from Tomsk. Post-horses everywhere available, rapid travelling in good weather, but bad carriages.

To astronomers bringing with them bulky instruments, the water-ways are to be recommended. St. Petersburg is in easy steamer communication with British harbours, and thence

I Just at the southern limit, it would be better to observe somewhat to the nortb.

2 See Mackenzie-Wallace's "Russia."
Inggage can be sent by water to. all parts of the Volga basin. So far as known at present, it is intended that there shall be observations of the eclipse at five points: (I) the observatory of General Maiewsky, Government of Tver ; (2) the estate of Count Olsuffiew, district Dmitrov, Government of Moscow; (3) the estate of Prof. Bredichin, district Kineschma, Government of Kostroma, - two English astronomers are expected ; (4) Glasov, Government of Viatka ; (5) Krasnoiarsk, on the Yenisei

A. WOEIKOF.

\section{Iridescent Clouds}

The clouds seen by Prof. Stone, as described in Nature, vol. $x \times x v$. p. $58 \mathrm{I}$, may have been of the same character (though I cannot judge positively from the description) as those so extensively observed in the Decembers of 1884 and 1885 ; if so, it is the only account $I$ have read of their being seen last winter. Those described by Mr. McConnel, writing from St. Moritz, Switzerland (p. 533), are evidently of a totally different character, and I suppose simply the ordinary iridescent clouds which are common everywhere.

Sunderland.

T. W. BACKHOUSE.

\section{Remarkable Hailstones.}

May I ask for space to make a suggestion as to the possible cause of the banded structure of hailstones recently observed and recorded in Nature, vol. xxxy. p. 438? It seems to me that the phenomenon may perhaps be explained by devitrification of the ice. We are familiar with a considerable number of bodies which assume the vitreous state by rapid solidification from the liquid state; and it seems reasonable to suppose that in the conditions under which hail is formed the ice may assume at first the vitreous state, the higher molecular structure of perfectly crystalline ice requiring more time for its full development (see paper by the writer read before Section $\mathrm{C}$ of the British Association last year at Birmingham). If such were the case (and the hypothesis is supported by the statement of Mr. C. S. Middlemiss in NATURE, rol. xxxv, p. 413), the observed structure (which can be actually seen to develop itself in some vitreous substances under the microscope, as a preliminary to the assumption of the full crystalline and opaque condition) would simply mark an early stage of the devitrifica. tion of the ice-glass. To bring this theory to the test of experiment it would only be necessary to observe closely the effect of keeping such hailstones for some time at a temperature rather below $0^{\circ} \mathrm{C}$

Wellington College, Berks, May 14.

A. IRVING.

\section{The Orbit of the Minor Planet Eucharis.}

ON reading your note (p. I6) on the determination of the orbit of the planet Eucharis, by Dr. de Ball, and the discordances between his observations and those obtained with the Washington meridian instrument, I am reminded of an earlier case which seems to me to be analogous.

Hansen drew attention to the very material difference between the observations of Egeria in 1864 at Bonn and Leyden. This discrepancy between observations which otherwise harmonized well amounted to $\mathbf{I O}^{\prime \prime}$ in R.A., and occasioned a protracted inquiry by Argelander (Astron. Nachr., No. 1769), in which he came to the conclusion that the reason probably lay in the personal error of the Leyden observer in the observation of bright and faint stars. As I am not acquainted with Dr. de Ball's treatise, I cannot judge whether respect was paid to such differences in isolated cases.

Karlsruhe Observatory, May 8.

\section{A Question for Chemists.}

YouR correspondent, Mr. West, will find reference to the fact that a mixture of glycerine and potassium permanganate is liable to spontaneous combustion in the "Extra Pharmacopœia" of Martindale and Westcott, fourth edition, p. 292.

Dublin.

HARRY NAPIER DRAPER.

\section{"A Junior Course of Practical Zoology."}

IN a recent notice of "A Junior Course of Practical Zoology" (NATURE, vol. xxxv. p. 506) the reviewer expresses surprise 